\title{
Discards of the Algarve (southern Portugal) crustacean trawl fishery
}

\author{
P. Monteiro, A. Araújo, K. Erzini \& M. Castro \\ Centre of Marine Sciences (CCMAR), Universidade do Algarve, Gambelas, 8000 Faro, Portugal \\ E-mail: pmontei@ualg.pt
}

Key words: crustacean fisheries, by-catch, discards, ecological impact

\begin{abstract}
The crustacean trawl fishery off the Algarve coast (southern Portugal) takes place on the lower continental shelf and upper continental slope at depths between 150 and $600 \mathrm{~m}$. This is a multi-species fishery targeting the shrimps Parapenaeus longirostris and Aristeus antennatus and the Norway lobster Nephrops norvegicus, with the latter two species the most important in the landings. The fishery is characterised by significant by-catch and discarding of a large number of species. As part of a study on the fate of trawl fishery discards, this component of the study focused on the quantification of the by-catch and discards of crustacean trawlers. Sampling took place on board seven commercial trawlers from June 1998 to October 1999. Data was collected from 48 tows in 22 fishing trips. The observers collected all of the catch that was discarded by the crew during the sorting operation and samples were taken to the laboratory for identification, weighing and measuring. The quantities of target species were recorded along with the presence of retained by-catch. Commercially valuable species that were retained included Plesiopenaeus edwardsianus, Aristeomorpha foliacea, Plesionika sp., and the fishes Lophius piscatorius and Merluccius merluccius. However, most of the species had no or little commercial value and were almost always discarded to the sea $(90 \%)$. A total of 91 species were identified, 47 vertebrates and 44 invertebrates corresponding to 65 families. The Teleostei (78\% and 68\%) were the dominant group, both in number and weight. The species Micromesistius poutassou (34\%), Gadiculus argenteus (10\%) and Hoplostethus mediterraneus (8\%) were the most important in weight. Ten species represented more than $82 \%$ of all discards in weight. Gadiculus argenteus (29\%), Hoplostethus mediterraneus (21\%) and Nezumia sclerorhynchus (10\%) accounted for $60 \%$ of all discards in numbers. Data on the landed species composition is also presented.
\end{abstract}

\section{Introduction}

The crustacean trawl fishery that takes place off the Algarve coast (South of Portugal) is of considerable importance due to the quantity and value of the landings. The most important crustacean fishing grounds in Portugal are located off this coast, contributing an annual crustacean catch of 984.3 tons in 1998 (D.G.P.P., 1999). This is a multispecies fishery targeting the shrimp Parapenaeus longirostris, the red shrimp Aristeus antennatus and the Norway lobster Nephrops norvegicus. In Portuguese waters, these species are found in areas on the continental shelf and upper slope between 80 and $700 \mathrm{~m}$ (S.E.P., 1984). Although their distributions overlap, $P$. longirostris prefers sandy mud or muddy sand bottoms between 200 and 400 m, while A. antennatus is more commonly found in muddy areas between 300 and $600 \mathrm{~m}$ (Cascalho, 1992). $N$. norvegicus has an irregular distribution between 200 and $700 \mathrm{~m}$ (S.E.P., 1984), depending on bottom topography and sediment type which is a limiting factor due to its burrowing behaviour (Figueiredo \& Viriato, 1992).

In the Algarve, this fishery takes place at depths greater than $150 \mathrm{~m}$ (S.E.P., 1984) following the depth distribution of each species and also in part because of the limitations imposed by legislation that prohibits trawling in areas within 6 miles from the shore. The species are targeted according to a number of factors including their availability, market demand and price (Arrobas, 1982).

As in others crustacean trawl fisheries around the world (Saila, 1983; Gray et al., 1990; Harris \& Poiner, 1990; Wassenberg \& Hill, 1990; Alverson et al., 1994; 
Borges et al., 1998; Merella et al., 1998), many other species to which effort is not directed are also caught (by-catch) since trawls are not very selective (Dayton et al., 1995; Kennelly, 1995). Globally, it has been estimated that 2.7 million $\mathrm{t}$ of by-catch were caught during prawn trawling in 1978, of which 1.4 million were discarded (Saila, 1983). According to Alverson et al., (1994), tropical shrimp trawl fisheries generate more discards than any other fishery and account for just over one-third of the global total. Borges et al. (1998) reported that the discards from the crustacean trawl fisheries in the Algarve ranged from 26\% to $91 \%$ of the catch in weight, with an average of $70 \%$.

A contributing factor to the by-catch problem in this fishery is the long tow duration, which is characteristic of this fishery. This leads to decreasing net size selectivity as the catch accumulates in the codend (Murawski, 1993). Part of the by-catch consists of crustaceans, fishes and molluscs with high commercial value and is landed. However, as in other crustacean fisheries most of the by-catch is composed of species of low or no commercial value and is discarded to the sea (Borges et al., 1997).

The difficulties of managing this fishery are largely due to its multi-species nature and to the lack of information on this developing fishery. Thus, there is at the moment no sustainable management scheme for the commercial species taking into account the bycatch. The by-catch of non-target species and their discarding may have negative consequences for noncommercial as well as commercial species due to influences on species interactions and consequent cascading effects throughout the trophic web (Hongskul, 1979; Saila, 1983; Harris \& Poiner, 1990; Hill \& Wassenberg, 1990; Alverson et al., 1994; McAllister \& Spiller, 1994; Kennelly, 1995; Yamamura, 1997). However, as Gulland (1972) pointed out, the effects of non-sustainable fishing may not be obvious for some years. Determination of the nature and extent of the ecological interactions between commercially valuable species and less valuable bottom species is important in managing shrimp fisheries and in exploiting demersal fish resources (Sheridan et al., 1984; Kennelly, 1995). Therefore, in an attempt at establishing a multi-species or ecosystem-based management approach to the crustacean trawl fishery of the Algarve, the quantification of by-catch composition and rates is a necessary pre-requisite. A sampling programme aboard commercial trawlers can be a way to characterise the biological diversity of the fishing grounds. Although Borges et al. (1997) have previously studied the discards of crustacean trawlers, the need for further and more in-depth studies was recognised.

Between June 1998 and October 1999, observers went on board Algarve trawlers. Their main goal was to quantify trawl discards and to assess their fate and importance to marine communities. This study reports the results concerning the species composition and quantities of discards in this fishery.

\section{Material and methods}

Trawl catches can vary within the same area, between areas and over time (Saila, 1983). Since this study was carried out on board commercial trawlers, it was not possible to select the sampling areas beforehand or to randomly stratify the sampling. Therefore, it was not possible to cover all the fishing grounds as the sampling was decided by the trawl skippers who based their decisions on economic considerations. We attempted to sample the greatest possible number of vessels given the available means.

The regular operation pattern aboard a crustacean trawler consists in an immediate separation on deck of commercially valuable species and the throwing back to sea of all the catch that will not be landed (discards). Since by definition discards are never landed, it was necessary to have observers on board the trawls. However, as a prerequisite, a sampling strategy was chosen that minimised interference with normal fishing operations. Observers collected all discards during the sorting process. The volume of fish discarded was estimated by placing discards in plastic $0.03 \mathrm{~m}^{3}$ fish boxes. Sub-samples were taken that ranged from at least a third of a box to a full box. The sub-samples were taken to laboratories where they were sorted into six main groups of species: Teleosts, Chondrichthyes, Crustacea, Cephalopoda, Gastropoda and Others. The latter group consisted mainly of benthic invertebrates. In the case of relatively small amounts of discards, the entire catch was brought to the laboratory. Although it was not possible to sample the discards of every tow, the main characteristics of each tow were recorded. For some tows, the discard samples were sorted and identified to the species level, and all the individuals measured and weighed.

The composition of the discard samples was used to estimate the total discard composition for each tow. The catch of crustacean target species per tow was estimated by counting the number of baskets of each species. Based on information provided by the skip- 
pers, the following average values per basket were used:

\author{
1. Nephrops norvegicus: $5 \mathrm{~kg}$, \\ 2. Plesiopenaeus edwardsianus: $5 \mathrm{~kg}$, \\ 3. Aristeomorpha foliacea: $5 \mathrm{~kg}$, \\ 4. Parapenaeus longirostris: $7 \mathrm{~kg}$, \\ 5. Aristeus antennatus: $7 \mathrm{~kg}$, \\ 6. Plesionika sp: $7 \mathrm{~kg}$.
}

Catches of $P$. edwardsianus and A. foliacea were estimated jointly because these species are not separated and are landed and sold together. It was not possible to obtain reliable data concerning the quantities of retained non-target fish and mollusc species per tow. This means that discard rate values were overestimated, because only landed crustaceans and discards were considered: $($ discard rate $=$ discards $(\mathrm{kg}) /$ (discards $(\mathrm{kg})+$ commercial crustaceans $(\mathrm{kg})$ ). However, the presence of by-catch species was noted. For each sampled tow, geographic co-ordinates and depth were recorded at the beginning and at the end of the tow. Towing speed and duration were also recorded.

Analysis of variance was used to study the discard variation according to the above six groups of species. The arc-sin of the square root was used to transform the proportion index of each group prior to analysis of variance (SAS Institute Inc., 1988).

\section{Results}

Sampling and study area

The observers went on 22 fishing trips during which 48 tows were sampled from seven trawlers. Most of the trawlers sampled were from the Port of Olhão; one of the most important in the Algarve and in Portugal, with the advantage of being located near the University where the samples were analysed (Fig.1). On two occasions, the fishing trips were carried out on the West Coast on board trawlers from the Port of Sines (Fig. 1). The seven trawlers that we sampled worked mainly in these two areas of the Portuguese coast.

As can be seen in Figure 1, fishing took place near the above mentioned ports in fairly limited areas and depths. The characteristics of the fishing operations are summarised in Table 1 . This fishery is characterised by tows of considerable duration, with a mean towing time of $5 \mathrm{~h}$ and $46 \mathrm{~min}(\mathrm{sd}=123 \mathrm{~min})$. The longest tow recorded was almost $12 \mathrm{~h}$ (Table 1). Trawling took place at a mean towing speed of 2.9 Knots (sd
Table 1. Towing duration, towing speed and fishing depth descriptive statistics. The depth values are from the beginning and the end of each tow

\begin{tabular}{llllll}
\hline & Mean & Minimum & Maximum & sd & $\mathrm{n}$ \\
\hline Towing (h: min) & $5: 46$ & $2: 55$ & $11: 37$ & $2: 03$ & 48 \\
Towing speed & 2.9 & 2.5 & 3.8 & 0.3 & 46 \\
$\begin{array}{l}\text { Knots) } \\
\text { Depth (m) }\end{array}$ & 433 & 95 & 657 & 172 & 96 \\
\hline
\end{tabular}

$=0.3$ Knots) (Table 1) and at a mean depth of $433 \mathrm{~m}$ $(\mathrm{sd}=172 \mathrm{~m})$, with a range from 95 to $657 \mathrm{~m}$.

\section{Discard catch composition}

Due to the conditions aboard the trawlers, it was not possible to collect discard samples from all 48 tows. For some of the tows, observers were limited to making observations and collecting some data on the catches. Discards from a total of 25 tows were sorted and weighed according to the six groups of species. The contribution by weight of each group for all 25 tows pooled together is shown in Figure 2.

As can be seen, Teleosts $(68 \%)$ and Chondrichthyes $(14 \%)$ dominated the by-catch by weight. Analysis of variance showed that the proportions between tows of the different groups were significantly different $(p<0.01)$. However, all the groups were always represented in the discard catch. Mean discards per tow were: $45.0 \mathrm{~kg}$ ( $\mathrm{sd}=40.5)$ Teleosts, $6.9 \mathrm{~kg}$ ( $\mathrm{sd}=$ 11.1) Chondrichthyes, $4.2 \mathrm{~kg}(\mathrm{sd}=7.2)$ Others, $2.7 \mathrm{~kg}$ $(\mathrm{sd}=5.0)$ Cephalopoda, $2.5 \mathrm{~kg}(\mathrm{sd}=2.8)$ Crustacea and $1.4 \mathrm{~kg}(\mathrm{sd}=2.3)$ Gastropoda. Teleosts $(78 \%)$ and Crustacea $(11 \%)$ dominated the discards in numbers in 14 tows where the numbers of each species were recorded (Fig. 3).

A total of 91 species were identified, 47 vertebrates and 44 invertebrates corresponding to 65 families. The families identified are distributed among the main groups of species as follows: Teleosts 29 (44.6\%), Crustaceans 18 (27.7\%), Others 8 (12.3\%), Chondrichthyes $4(6.2 \%)$, Cephalopoda $4(6.2 \%)$ and Gastropoda 2 (3.1\%) (Tables 2 and 3).

The 10 most important species in number and weight are listed in Tables 4 and 5. As can be seen in Table 4, 9 fish and 1 crustacean species accounted for more than $82 \%$ of all the discarded biomass. The species Micromesistius poutassou (34\%), Gadiculus argenteus (10\%) and Hoplostethus mediterraneus $(8 \%)$ were the three most important species 
Table 2. Invertebrate discard species composition by number and weight

\begin{tabular}{|c|c|c|c|c|}
\hline Species & Family & $\begin{array}{l}\text { Species } \\
\text { group }\end{array}$ & $\begin{array}{l}\text { Percent of } \\
\text { total weight } \\
\text { (16 tows) }\end{array}$ & $\begin{array}{l}\text { Percent of } \\
\text { total number } \\
\text { (14 tows) }\end{array}$ \\
\hline Actinauge richardi & Hormathiidae & Others & 1.1834 & 1.2203 \\
\hline Anseropoda placenta & Asterinidae & Others & 0.0002 & 0.0032 \\
\hline Aphrodite aculeata & Aphroditidae & Others & 0.0166 & 0.0097 \\
\hline Argobuccinum olearium & Cymatiidae & Gastropoda & 1.4961 & 0.3485 \\
\hline Aristeus antennatus & Aristeidae & Crustacea & 0.0915 & 0.4516 \\
\hline Astropecten aranciacus & Astropectinidae & Others & 0.0030 & 0.0258 \\
\hline Bathynectes maravigna & Portunidae & Crustacea & 1.9126 & 4.2961 \\
\hline Calappa granulata & Calappidae & Crustacea & 0.3416 & 0.1224 \\
\hline Calliactis parasitica & Hormathiidae & Others & 0.1223 & 0.3477 \\
\hline Cassidaria tyrrhena & Cassidae & Gastropoda & 0.4980 & 0.4089 \\
\hline Charonia lampas & Cymatiidae & Gastropoda & 0.0507 & 0.0032 \\
\hline Dardanus arrosor & Diogenidae & Crustacea & 0.1368 & 0.1996 \\
\hline Echinus acutus & Echinidae & Others & 0.0158 & 0.0773 \\
\hline Eledone moschata & Octopodidae & Cephalopoda & 0.4154 & 0.0773 \\
\hline Geryon longipes & Geryonidae & Crustacea & 0.2788 & 0.0869 \\
\hline Goneplax rhomboides & Goneplacidae & Crustacea & 0.0018 & 0.0193 \\
\hline Homola barbata & Homolidae & Crustacea & 0.0149 & 0.0547 \\
\hline Illex coindetii & Ommastrephidae & Cephalopoda & 0.5064 & 0.0676 \\
\hline Liocarcinus depurator & Portunidae & Crustacea & 0.1829 & 0.4701 \\
\hline Macropipus tuberculatus & Portunidae & Crustacea & 0.0893 & 0.4194 \\
\hline Monodaeus couchii & Xanthidae & Crustacea & 0.0009 & 0.0032 \\
\hline Munida rugosa & Galatheidae & Crustacea & 0.0485 & 0.1449 \\
\hline Neorossia caroli & Sepiolidae & Cephalopoda & 0.1432 & 0.1964 \\
\hline Nephrops norvegicus & Nephropidae & Crustacea & 0.0932 & 0.0869 \\
\hline Octopus salutii & Octopodidae & Cephalopoda & 0.0116 & 0.0064 \\
\hline Ophiura texturata & Ophiuridae & Others & 0.0580 & 0.5023 \\
\hline Pagurus alatus & Paguridae & Crustacea & 0.0183 & 0.1642 \\
\hline Pagurus sp. & Paguridae & Crustacea & 0.0130 & 0.0853 \\
\hline Parapenaeus longirostris & Penaeidae & Crustacea & 0.2810 & 0.7124 \\
\hline Parthenope macrochelos & Parthenopidae & Crustacea & 0.0021 & 0.0032 \\
\hline Pasiphaea sivado & Pasiphaeidae & Crustacea & 0.0004 & 0.0129 \\
\hline Plesionika ensis & Pandalidae & Crustacea & 0.1437 & 0.8726 \\
\hline Polybius henslowii & Portunidae & Crustacea & 0.7009 & 2.2459 \\
\hline Polycheles typhlops & Polychelidae & Crustacea & 0.1390 & 0.3027 \\
\hline Pontocaris lacazei & Crangonidae & Crustacea & 0.0002 & 0.0032 \\
\hline Rossia macrosoma & Sepiolidae & Cephalopoda & 0.3250 & 0.1256 \\
\hline Scaeurgus unicirrhus & Octopodidae & Cephalopoda & 0.0110 & 0.0097 \\
\hline Scalpellum scalpellum & Scalpellidae & Crustacea & 0.0020 & 0.0064 \\
\hline Sepia elegans & Sepiidae & Cephalopoda & 0.0556 & 0.0869 \\
\hline Sepia orbignyana & Sepiidae & Cephalopoda & 0.0033 & 0.0032 \\
\hline Sepietta oweniana & Sepiolidae & Cephalopoda & 0.0029 & 0.0193 \\
\hline Sphaerechinus granularis & Toxopneustidae & Others & 0.0113 & 0.1811 \\
\hline Stichopus regalis & Stichopodidae & Others & 0.0653 & 0.0483 \\
\hline Todaropsis eblanae & Ommastrephidae & Cephalopoda & 0.7491 & 0.1288 \\
\hline
\end{tabular}


Table 3. Vertebrate discard species composition by weight and number

\begin{tabular}{|c|c|c|c|c|}
\hline Species & Family & $\begin{array}{l}\text { Species } \\
\text { group }\end{array}$ & $\begin{array}{l}\text { Percent of } \\
\text { total weight } \\
\text { (16 tows) }\end{array}$ & $\begin{array}{l}\text { Percent of } \\
\text { total number } \\
\text { (14 tows) }\end{array}$ \\
\hline Antonogadus megalokynodon & Gadidae & Teleost & 0.0393 & 0.0998 \\
\hline Breviraja sp. & Rajidae & Chondrichthyes & 0.0137 & 0.0386 \\
\hline Capros aper & Caproidae & Teleost & 0.0100 & 0.0129 \\
\hline Chaunax pictus & Chaunacidae & Teleost & 0.0218 & 0.0386 \\
\hline Chimaera monstrosa & Chimaeridae & Chondrichthyes & 0.8093 & 0.0773 \\
\hline Chlorophthalmus agassizii & Chlorophthalmidae & Teleost & 0.0390 & 0.0483 \\
\hline Citharus linguatula & Citharidae & Teleost & 0.0250 & 0.0161 \\
\hline Coelorhynchus coelorhynchus & Macrouridae & Teleost & 0.8938 & 0.6536 \\
\hline Conger conger & Congridae & Teleost & 3.5381 & 0.6222 \\
\hline Dalatias licha & Squalidae & Chondrichthyes & 0.0362 & 0.0032 \\
\hline Deania calceus & Squalidae & Chondrichthyes & 0.5008 & 0.2165 \\
\hline Dicologoglossa cuneata & Soleidae & Teleost & 0.0012 & 0.0072 \\
\hline Diretmoides parini & Diretmidae & Teleost & 0.0033 & 0.0032 \\
\hline Etmopterus pusillus & Squalidae & Chondrichthyes & 1.6802 & 0.6061 \\
\hline Etmopterus spinax & Squalidae & Chondrichthyes & 4.8522 & 2.3763 \\
\hline Facciolella oxyrhyncha & Nettastomatidae & Teleost & 0.0321 & 0.0354 \\
\hline Gadiculus argenteus & Gadidae & Teleost & 9.8148 & 29.4038 \\
\hline Galeus melastomus & Scyliorhinidae & Chondrichthyes & 5.2697 & 3.4597 \\
\hline Helicolenus dactylopterus & Scorpaenidae & Teleost & 0.6209 & 0.1642 \\
\hline Hoplostethus mediterraneus & Trachichthyidae & Teleost & 8.1397 & 20.7697 \\
\hline Lepidopus caudatus & Trachiuridae & Teleost & 0.5007 & 0.1803 \\
\hline Lepidorhombus boscii & Scophthalmidae & Teleost & 0.2300 & 0.1127 \\
\hline Lophius piscatorius & Lophiidae & Teleost & 0.1572 & 0.0773 \\
\hline Macroramphosus scolopax & Macroramphosidae & Teleost & 0.1367 & 0.2286 \\
\hline Malacocephalus laevis & Macrouridae & Teleost & 3.3191 & 1.1664 \\
\hline Merluccius merluccius & Merlucciidae & Teleost & 0.5369 & 0.5611 \\
\hline Micromesistius poutassou & Gadidae & Teleost & 33.9307 & 9.7803 \\
\hline Mora moro & Moridae & Teleost & 0.0470 & 0.1352 \\
\hline Myctophidae & Myctophidae & Teleost & 0.0006 & 0.0097 \\
\hline Nemichthys scolopaceus & Nemichthyidae & Teleost & 0.0046 & 0.0386 \\
\hline Nezumia sclerorhynchus & Macrouridae & Teleost & 7.8355 & 10.1047 \\
\hline Notacanthus bonapartei & Notacanthidae & Teleost & 0.0114 & 0.0169 \\
\hline Notacanthus chemnitzii & Notacanthidae & Teleost & 0.0059 & 0.0072 \\
\hline Ophisurus serpens & Ophichthidae & Teleost & 0.0093 & 0.0032 \\
\hline Peristedion cataphractum & Peristediidae & Teleost & 0.0093 & 0.0097 \\
\hline Phycis blennoides & Gadidae & Teleost & 3.7271 & 2.1758 \\
\hline Polymetme corythaeola & Photichthyidae & Teleost & 0.6793 & 1.4618 \\
\hline Raja oxyrinchus & Rajidae & Chondrichthyes & 0.0079 & 0.0097 \\
\hline Raja sp. & Rajidae & Chondrichthyes & 0.0657 & 0.0676 \\
\hline Scomber scombrus & Scombridae & Teleost & 0.0942 & 0.0451 \\
\hline Scyliorhinus canicula & Scyliorhinidae & Chondrichthyes & 1.4490 & 0.1030 \\
\hline Serranus hepatus & Serranidae & Teleost & 0.0101 & 0.0322 \\
\hline Symphurus ligulatus & Cynoglossidae & Teleost & 0.0067 & 0.0274 \\
\hline Synaphobranchus kaupi & Synaphobranchidae & Teleost & 0.0377 & 0.1884 \\
\hline Trachurus picturatus & Carangidae & Teleost & 0.3621 & 0.0773 \\
\hline Trachurus trachurus & Carangidae & Teleost & 0.2381 & 0.0362 \\
\hline Venefica proboscidea & Nettastomatidae & Teleost & 0.0090 & 0.0290 \\
\hline
\end{tabular}




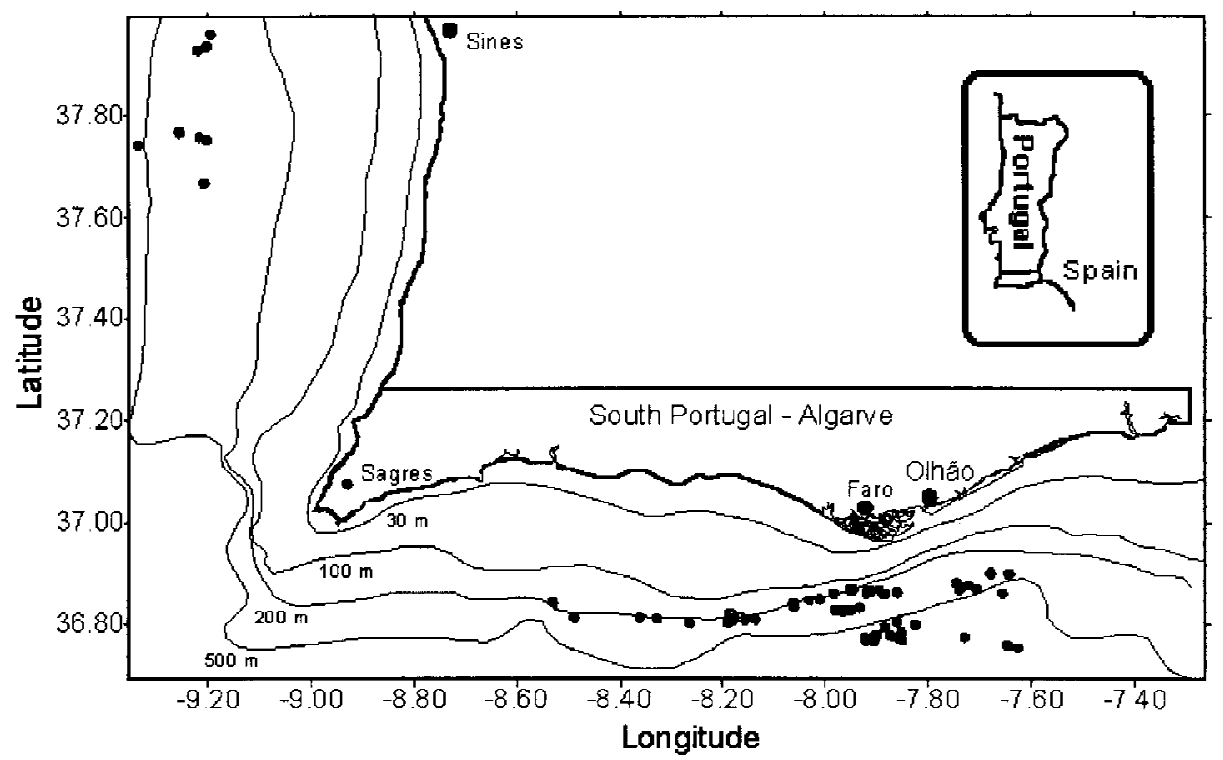

Figure 1. Geographic location of each tow. Each point marks the beginning or end of a tow.

Table 4. Percentage of total weight of top 10 main discard species (16 tows)

\begin{tabular}{llc}
\hline Species & Species group & Percent \\
\hline Micromesistius poutassou & Teleost & 33.93 \\
Gadiculus argenteus & Teleost & 9.82 \\
Hoplostethus mediterraneus & Teleost & 8.14 \\
Nezumia sclerorhynchus & Teleost & 7.84 \\
Galeus melastomus & Chondrichthyes & 5.27 \\
Etmopterus spinax & Chondrichthyes & 4.85 \\
Phycis blennoides & Teleost & 3.73 \\
Conger conger & Teleost & 3.54 \\
Malacocephalus laevis & Teleost & 3.32 \\
Bathynectes maravigna & Crustacea & 1.91 \\
Total & & $\mathbf{8 2 . 3 5}$ \\
\hline
\end{tabular}

in weight. However, species that were important in weight were not necessarily as important in discard numbers. As is shown in Table 5, Gadiculus argenteus (29\%), Hoplostethus mediterraneus (21\%) and Nezumia sclerorhynchus (10\%) accounted over $60 \%$ of all discards in numbers.

As seen in Tables 4 and 5 the major discard species, in number and weight, are essentially all Teleosts and Chondrichthyes. The only two species from the other major groups were Bathynectes maravigna (Crustacea) and Polybius henslowii (Crustacea).
Table 5. Percentage of total number of top 10 main discard species (14 tows)

\begin{tabular}{llc}
\hline Species & Species group & Percent \\
\hline Gadiculus argenteus & Teleost & 29.40 \\
Hoplostethus mediterraneus & Teleost & 20.77 \\
Nezumia sclerorhynchus & Teleost & 10.11 \\
Micromesistius poutassou & Teleost & 9.78 \\
Bathynectes maravigna & Crustacea & 4.30 \\
Galeus melastomus & Chondrichthyes & 3.46 \\
Etmopterus spinax & Chondrichthyes & 2.38 \\
Polybius henslowii & Crustacea & 2.25 \\
Phycis blennoides & Teleost & 2.18 \\
Polymetme corythaeola & Teleost & 1.46 \\
& & \\
Total & & $\mathbf{8 6 . 0 7}$ \\
\hline
\end{tabular}

Target crustaceans identified in the discards essentially consisted of specimen parts and were relatively unimportant in the discards. This component of the discards resulted from damage in the net and during the sorting process. Merluccius merluccius, an important commercial species, was discarded quite frequently, with most discards consisting of individuals below the minimum landing size of $27 \mathrm{~cm}$ total length. Commercial fish species were also occasionally discarded because of legislation limiting the percentage 


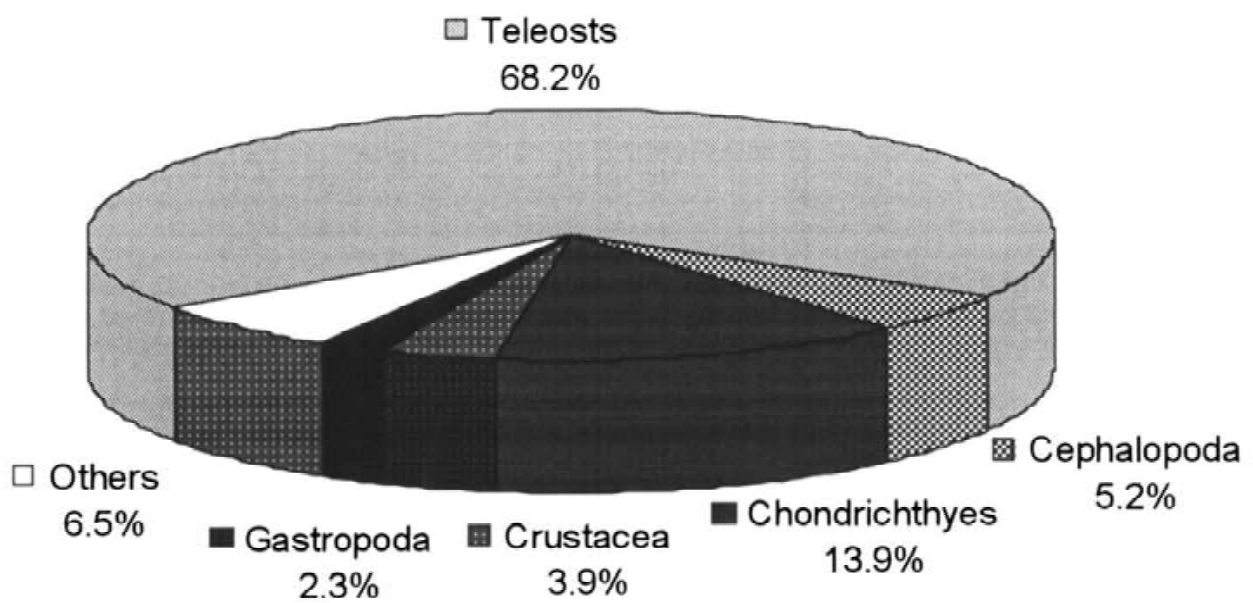

Figure 2. Discard composition by main species groups in weight. Pooled information from 25 tows.

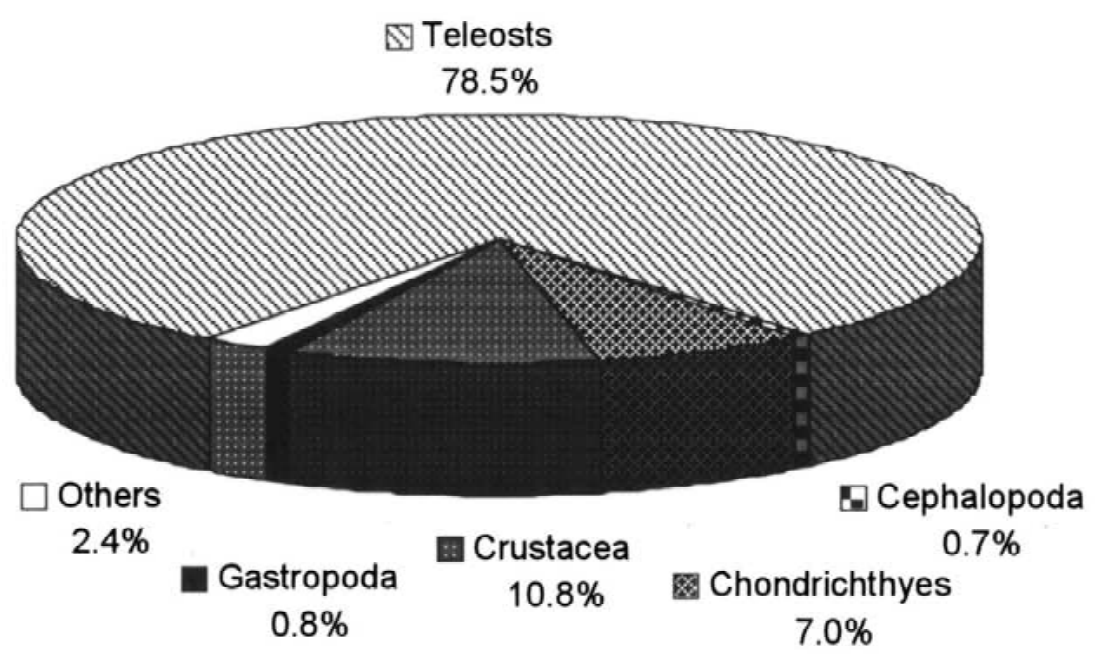

Figure 3. Discard composition by main species groups in number. Pooled information from 14 tows.

of fish by-catch that can be landed in this crustacean trawl fishery.

\section{Landed catch and discard rate}

The mean commercial crustacean catch per tow was 97 $\mathrm{kg}$, ranging from a minimum of $10 \mathrm{~kg}$ to a maximum of $248 \mathrm{~kg}$ (Table 6). Discarded species varied from 6 $\mathrm{kg}$ to $170 \mathrm{~kg}$ per tow, with a mean of $58 \mathrm{~kg}$ per tow (Table 6). The mean discard rate per tow was $37 \%$ (sd $=21$ ) ranging from $5 \%$ to $76 \%$ (Table 6 ).

As expected, the most frequent species were the three major species of this fishery: the shrimp $P$. longirostris, the red shrimp A. antennatus and the Norway lobster $N$. norvegicus. Figure 4 shows the frequency of occurrence in the sampled tows of the com- mercial crustacean species. Parapenaeus longirostris was the most frequently caught with $97 \%$ occurrence. The Norway lobster and red shrimp had similar frequencies, respectively, $56 \%$ and $45 \%$. Three other crustacean species, A. foliacea, P. edwardsianus and Plesionika sp., having high commercial value were also landed but less frequently caught. Figure 5 shows the mean catches in weight, per tow, of each of the commercial crustacean species.

In addition to the above commercial crustaceans, 21 species of fishes and molluscs of commercial value were also caught as by-catch (Fig. 6). However, only two species (hake, Merluccius merluccius and angler fish Lophius piscatorius) occurred frequently as landed by-catch with $91 \%$ and $70 \%$ of frequency of presence, which, due to their high value, made 
Table 6. Mean catches of landed crustacean and discard species per tow in the trawl fishery

\begin{tabular}{llllll}
\hline & Mean & Minimum & Maximum & sd & $n$ \\
\hline Discard species (Kg) & 58.1 & 6.2 & 169.1 & 45.6 & 28 \\
Landed crustacean species (Kg) & 96.9 & 9.6 & 248.5 & 57.9 & 37 \\
Discard rate (\%) & 37.5 & 5.4 & 76.1 & 21.0 & 23 \\
\hline
\end{tabular}

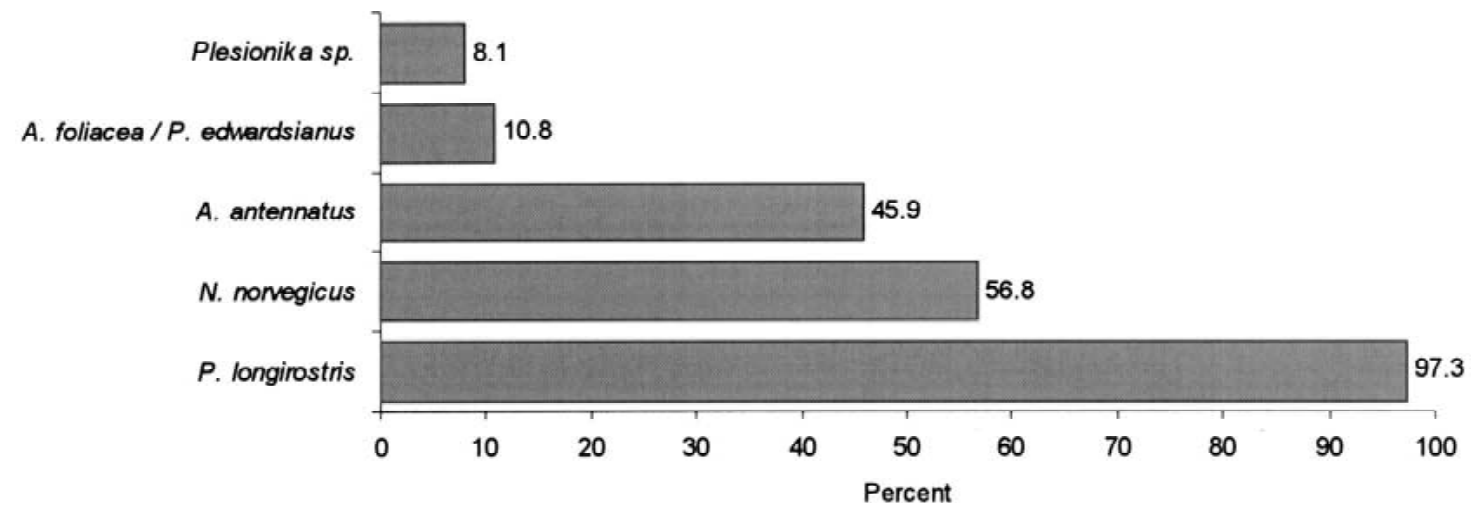

Figure 4. Frequency of presence of main target crustacean species. Pooled information from 37 tows.

important contributions to the value of the landings (Fig. 6). The remaining species were occasional in the landed catch and occurred in less than $50 \%$ of the tows (Fig. 6). They were generally discarded due to low value and/or small quantities caught.

\section{Discussion}

Long tows along with the non-selective characteristics of the trawl net used lead to the capture of considerable quantities of by-catch per tow. Discard quantities and rates in this study were high but less than those reported by Borges et al. (1997) for the same fishery. The discarded proportion of the catch in the latter study ranged from 26 to $91 \%$ of the catch in weight, with an average of $70 \%$. The difference in results is even higher if we consider that in the present study, the biomass comprising landed by-catch was not taken into consideration in the calculation of discard rates. These differences between the findings of the two studies can only be explained by inter-annual variability, with marked differences in the abundance of some of the key Teleost discard species from year to year. As in the previous study (Borges et al., 1997), discards were dominated by a few vertebrate and invertebrate species. These two groups had almost the same specific richness in the catch; 47 vertebrate and 44 invertebrate discard species were identified, respectively. However, there were significant differences in terms of biomass and numbers, with Teleosts and Chondrichthyes accounting for $82 \%$ and $85 \%$ of the total discards in weight and number. Although catches varied considerably in terms of specific composition from tow to tow, the relative importance of each of the six main species groups was fairly constant.

Discarded by-catches were dominated by 10 species of which the most important by number and weight were $M$. poutassou, G. argenteus, $H$. mediterraneus and $N$. sclerorhynchus. These four species represented about 60 and $70 \%$ of all discards in this study, respectively, by number and weight. These results are somewhat different from the ones obtained in the study by Borges et al. (1997), where a greater number of species were reported. There was a significant difference in terms of specific composition between the two studies. Whereas, for example, in the current study M. poutassou (34\%) was the dominant species in terms of weight, in the previous study it was the sixth most important species, behind Torpedo nobeliana (14.8\%), S. canicula (14.6\%), C. conger (10.4\%), C. aper (6.0\%) and M. merluccius (4.8\%). T. nobeliana was not caught at all in the present study. 


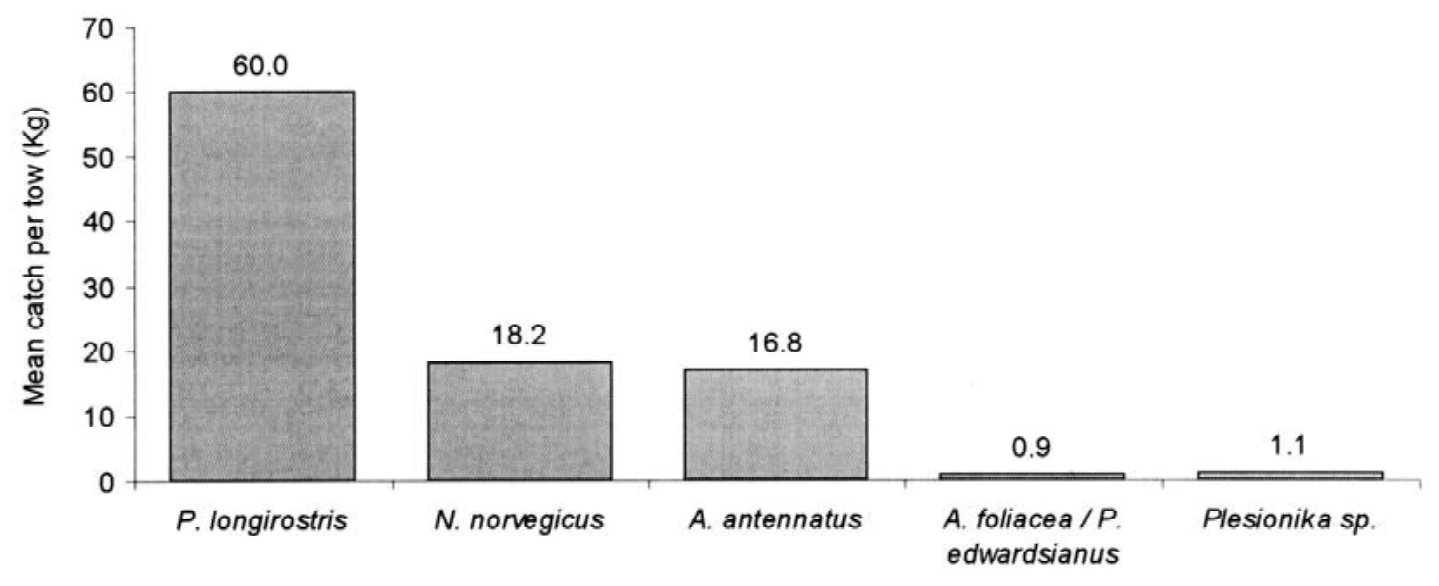

Figure 5. Mean catch in kilograms, per tow, of the main target crustacean species. Pooled information from 33 tows.

As noted above, these differences are probably due to inter-annual variability and changes in abundance, in particular of small, schooling species such as $M$. poutassou and C. aper.

Only a few other studies have examined discards in southern European or nearby waters. Balguerías (1997) studied the discards of the cephalopod trawl fishery on the continental shelf off the Saharan coast $\left(21^{\circ} \mathrm{N}-26^{\circ} \mathrm{N}\right)$ and reported a mean discard rate of $66 \%$ of the total catch with discards consisting of at least 60 fish species. Invertebrates were a significant component of the discards and the fish discards consisted mainly of small pelagics and under-sized sea breams (Sparidae).

Tursi (1994) sampled two trawlers once a month in the Mediterranean (Ionian Sea), and found that a total of 64 fish species were discarded. Of these, 29 had no commercial value while 36 were discarded because the fish were under-sized. The two trawlers discarded $47 \%$ and $45 \%$ of the catch in weight.

The first comprehensive study of trawl discards in the western Mediterranean (Spain and Italy) was carried out with sampling on board commercial trawlers from June 1995 to June 1996 (Carbonell, 1997). Stratification was by port (7) and depth (A: $<150 \mathrm{~m}$, $\mathrm{B}: 151-350 \mathrm{~m}$, and C:> $350 \mathrm{~m}$ ). Additionally, trawl type (2) and horse power $(<,>150$ h.p.) were also used to stratify the sampling in two of the seven ports. A total of 609 species in 14 major taxonomic groups were caught, of which only $20 \%$ were commercially exploited and landed. Fish dominated the discards ( Osteichthyes: 128 species and Chondrychthyes: 24 species). Discarding rates were highly variable, with means ranging from $13.1 \%$ to $52.5 \%$ of the total catch among the different ports. Depth was an important factor influencing commercial fraction, discard rates, discard composition and reasons for discarding. The discarded biomass ranged from a low of $2.2 \mathrm{~kg} / \mathrm{h}$ at depths greater than $350 \mathrm{~m}$ to $118.3 \mathrm{~kg} / \mathrm{h}$ in the lower depth stratum. Invertebrates and algae contributed significantly to the discards in stratum A, while potentially commercial species were particularly important in stratum B and non-commercial species dominated at the greater depths.

More information is needed to improve our understanding of the impact of discarding on multi-species fisheries such as the one studied here. The exploited species are interdependent through competition and predator-prey relationships. In addition to the direct impact on populations of discard related mortality, there are ecosystem and trophic level effects which are poorly understood. Any effect on one stock, population or species may produce a change in another, resulting in readjustment in both populations (Hongskul, 1979; Saila, 1983; Alverson et al., 1994; McAllister \& Spiller, 1994; Kennelly, 1995).

There is some evidence that the introduction of food in the form of discards to scavengers can lead to significant ecological changes (Harris \& Poiner, 1990; Wassenberg \& Hill, 1990; Alverson et al., 1994; Kennelly, 1995; Yamamura, 1997). Discards represent an introduction of more or less localised but important quantities of energy and may constitute a perturbation of the trophic system, resulting in significant non-selective predation and scavenging. This energy is often directly available to the higher trophic levels, namely marine birds and large demersal scavengers such as sharks. Pauly \& Christensen (1995) reported 


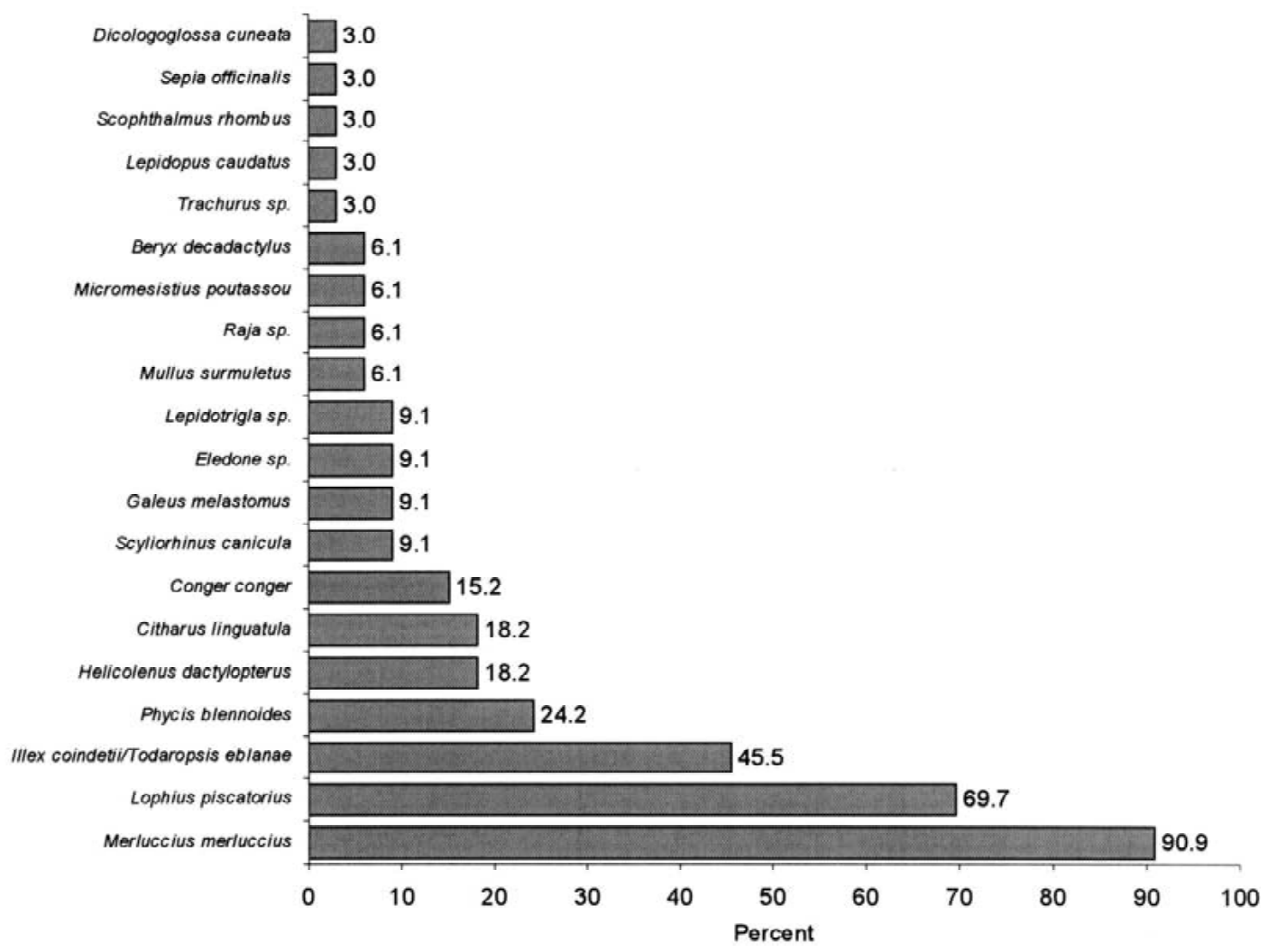

Figure 6. Landed by-catch species' frequency of presence. Pooled information from 33 tows.

that the contribution of recycled discards to the energy budget may be significant in some marine ecosystems and discards were shown to contribute a significant part of the diet of many species of sea birds in areas such as the North Sea (Garthe et al., 1996).

Future studies must focus on understanding the fate of discards, their impact on the marine ecosystem and on mitigation. From an economic perspective, there are possibilities of making a better use of some discarded species, thereby possibly reducing the pressure on target species. Technical measures such as the use of square meshes and grids can be used to significantly reduce by-catch in trawl fisheries (Kennelly, 1995). The critical fact is that sustainable management of fishing resources must take place in the ecosystem context, with a good understanding of all the possible effects of fishing activities.

\section{Acknowledgements}

This work was funded in part by the Commission of the European Communities DG XIV/C/1, Project ref. 96-063 (Methodologies to study the impact of discards in trawl fisheries). The authors wish to express their gratitude to the skippers and boat owners who allowed our presence on board for data collection, the fishermen for their co-operation and our colleague João Sendão who helped with the cephalopod identification.

\section{References}

Alverson, D. L., M. H. Freeberg, S. A. Murawski \& J. G. Pope, 1994. A global assessment of fisheries bycatch and discards, FAO Fisheries Technical Paper, No 339, Rome: 233 pp.

Arrobas, I., 1982. Some aspects of the biology and fishery of Nephrops norvegicus (L.) from the south Portuguese coast. Shellfish and Benthos Committee, ICES C.M. 1982/K:27, Lisboa, Portugal: $11 \mathrm{pp}$.

Balguerías, E. G., 1997. Discards in fisheries from the eastern central Atlantic (CECAF Region). In Clucas, I. J. \& D. G. James (eds), Papers Presented at the Technical Consultation on Reduction of Wastage in Fisheries, Tokyo, Japan, 28 Oct.-1 Nov. 1996. FAO Fish. Rep. 547: 183-214.

Borges, T. C., L. Bentes, M. Castro, M. E. Costa, K. Erzini, J. Gomes, J. M. S. Gonçalves, P. G. Lino, C. Pais \& J. Ribeiro, 1997. Studies of the discards of commercial fisheries from 
the south of Portugal. Final Report to the Commission of the European Communities, DG XIV-C-1, Study Project No. 95/081.

Carbonell, A. (Coordinator), 1997. Discards of the western Mediterranean trawl fleets. Commission of the European Communities, Final Report, Contract Np DGXIV-MED/94/027.

Cascalho, A. R., 1992. A pescaria de gamba e camarão vermelho. Questões principais inerentes à gestão desta pescaria como medida de conservação de recursos. In Instituto Nacional de Investigação Pesqueira (I.N.I.P.)/Liga para a Protecção da Natureza (L.P.N.) (eds), Colóquio Sobre Conservação Dos Recursos Vivos Marinhos. Lisboa, Portugal, 25-27 Novembro. 1989. Publicações avulsas do I.N.I.P. 17: 97-106.

Dayton, P. K., S. F. Thrush, M. T. Agardy \& R. J. Hofman, 1995. Viewpoint: environmental effects of marine fishing. Aquat. Cons.: Mar. Freshwat. Ecosys. 5: 205-232

De Figueiredo, M. J. \& A. Viriato, 1992. Distribuição batimétrica e topografia dos pesqueiros de Lagostim (Nephrops norvegicus) na costa portuguesa. In Instituto Nacional de Investigação Pesqueira (I.N.I.P.)/Liga para a Protecção da Natureza (L.P.N.) (eds), Colóquio Sobre Conservação Dos Recursos Vivos Marinhos. Lisboa, Portugal, 25-27 Novembro. 1989. Publicações avulsas do I.N.I.P.: 17,95

D. G. P. P (Direcção Geral Planeamento das Pescas), 1999. Recursos da Pesca. Série Estatística, Direcção-Geral das Pescas e Aquicultura (DGPA), Lisboa, 11A-B: 172 pp.

Garthe, S., C. J. Camphuysen \& R. W. Furness, 1996. Amounts of discards by commercial fisheries and their significance as food for seabirds in the North Sea. Mar. Ecol. Prog. Ser. 136: 1-11.

Gray, C. A., V. C. McDonall \& D. D. Reid, 1990. By-catch of prawn trawling in the Hawkesbury River, New South Wales: species composition, distribution and abundance. Aust. J. mar. Freshwat. Res. 41: 13-26.

Gulland, J. A., 1972. Some introductory guidelines to management of shrimp fisheries. Indian Ocean Fishery Commission. Dev. Progr. 24: 1-12.

Harris, A. N. \& I. R. Poiner, 1990. By-catch of prawn fishery of Torres Strait, Composition and partitioning of the discards into components that float or sink. Aust. J. mar. Freshwat. Res. 41: 37-52.

Hill, B. J. \& T. J. Wassenberg, 1990. Fate of discards from prawn trawlers in Torres Strait. Aust. J. mar. Freshwat. Res. 41: 53-64.

Hongskul, V., 1979. Report on the studies of multispecies systems in fisheries. In stock Assessment in Tropical Small-Scale Fisher- ies, Proceedings of an international workshop, September 19-21. 1979. U.R.I.: 173-182.

Kennelly, S. J., 1995. The issue of bycatch in Australia's demersa trawl fisheries. Rev. Fish Fish. 5: 213-234.

McAllister, D. E. \& G. Spiller, 1994. Fish habitat: Trawling and dredging impact on fish habitat and bycatch. In Wells, P. G. \& P. J. Ricketts (eds), Coastal Zone Canada' 94, Cooperation in the Coastal Zone: Conference Proceedings, September 20-23. 1994. Coastal Zone Canada Association, Halifax, Canada: 4: 17081717.

Merella, P., F. Alemany, A. Carbonell. \& A. Quetglas, 1998. Fishery and biology of Norway lobster Nephrops norvegicus (Decapoda: Nephropidae) in Mallorca (Western Mediterranean). J. Nat. Hist. 32: $1631-1640$.

Murawski, S. A., 1993. Factors Influencing Bycatch and Discard Rates: Analyses from Multispecies/Multifishery. In: Scientific Council Meeting - September 13-15, 1993. NAFO SCS Doc. 93/115, Serial No N2309, Dartmouth, Canada: 8 pp.

Pauly, D. \& V. Christensen, 1995. Primary production required to sustain global fisheries. Nature 374: 255-257.

Saila, S. B., 1983. Importance and assessment of discards in commercial fisheries. FAO Fish. Circ. no. 765: 62 pp.

SAS Institute Inc., 1988. SAS/STATTM User's Guide, Release 6.03 Edition. Cary, NC: 1028 pp.

S.E.P. (Secretaria Estado das Pescas), 1984. Programa de reestruturação, modernização e desenvolvimento da frota de pesca portuguesa. Ministério da Agricultura e Pescas e Alimentação, Secretaria de Estado das Pescas (S.E.P.), Lisboa: 75 pp.

Sheridan, P. F., J. A. Browder \& J. E. Powers, 1984. Interaction with other species. Ecological interactions between penaeid shrimp and bottomfish assemblages. In Guland J. A. \& B. J. Rothschild (eds), Workshop on the Scientific Basis for the Management of Penaeid Shrimp, November 1981. Fishing News Books, Surrey, England: 235-254.

Tursi, A., 1994. Length and age composition of ichthyc species present in discards from commercial fishing in the Ionian Sea. Final Report, Commission of the European Communities, DG XIV-C-1, Contract No 1992/14.

Wassenberg, T. J. \& B. J. Hill, 1990. Partitioning of material discarded from prawn trawlers in Moreton Bay. Aust. J. mar. Freshwat. Res. 41: 27-36.

Yamamura, O., 1997. Scavenging on discarded saury by demersal fishes off Sendai Bay, northern Japan. J. Fish Biol. 50: 919-925. 